\title{
Internet resources for psychiatry and neuropsychiatry
}

\section{J Stone, M Sharpe}

J Neurol Neurosurg Psychiatry 2003;74:10-12

Some of the most useful internet resources relevant to psychiatry and neuropsychiatry are summarised. Web sites recommended for professionals and patients are detailed, including where to find evidence based psychiatry, psychiatry news, and professional organisations. Some thoughts on "cyberchondria" and the opportunities that the internet offers for illness transmission are also considered.

See end of article for authors' affiliations

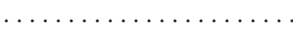

Correspondence to: Dr J Stone, Department of Clinical Neurosciences, Western General Hospital, Crewe Rd, Edinburgh EH4 2XU, UK:

jstone@skull.den.ed.ac.uk
A ny quick search on the web quickly indicates that the number of psychiatry, psychology, and mental health pages overwhelm those specifically about clinical neurosciences. In this article we focus on the psychiatry and neuropsychiatry related sites that in our opinion are the most useful, of particular interest to the readers of the $J N N P$, and have the best links to help you explore other web sites relevant to psychiatry most efficiently (table 1).

Readers are reminded that information about medicine and the internet (including file transfer protocol servers, search engines, e-prints, and email) can be found in the first article in this series. ${ }^{1}$ Further information about internet resources in psychiatry can also be found in a book, The insider's guide to mental health resources. ${ }^{2}$

CLINICAL AND EDUCATIONAL MATERIAL Evidence based psychiatry, databases, and journals

More specifically evidence based psychiatry is relatively hard to come by on the web. Perhaps the most useful site is that of the Centre for Evidence Based Mental Health (http://cebmh. warne.ox.ac.uk/cebmh) in Oxford. The Cochrane Collaboration (www.cochrane.org) also has a Depression Anxiety \& Neurosis Group, a Dementia Group, and a Schizophrenia Group, all with high quality systematic review abstracts available free online. Clinical Evidence (www.clinicalevidence.com) also allows access to reviews of similar quality by subscription-or free if you are an NHS professional in the United Kingdom. Access is also free or at greatly reduced cost to many of the poorer countries in the world.

For anyone carrying out a literature search, Psycinfo, produced by the American Psychological Association, is a database of psychiatric and psychologically oriented literature similar to Medline but with access to books from 1987 and article titles going back to 1887. Psycinfo is usually available through university libraries (in the United Kingdom through BIDS (www.bids.ac.uk)).

The best of a number of journal directories is provided by Psycline (www.psycline.org). Most journals now offer online abstract, full text, and table of contents by email. There is a welcome trend of some journals providing free full text access to back issues. Table 2 lists some of the more popular journals.

\section{Other general sites}

One of the most educational general psychiatry sites is Internet Mental Health (www.mental health.com) maintained by Philip Long. It contains descriptions of mental disorders based on Diagnostic and statistical manual of mental disorders, fourth edition, and International classification of diseases, as well as numerous well organised links, including to patient information booklets. Sadly, a subscription is now required for the online diagnosis program. Mental Help Net (http:// mentalhelp.net) is another huge site with a good set of links. Other useful starting places for psychiatry links are www.psychiatrist.com and About Mental Health Resources (http:// mentalhealth.miningco.com).

Self assessment is available through the psychiatry web site of the New York University School of Medicine (www.med.nyu.edu/Psych/ itp.html). This site has over 200 multiple choice questions that can be marked on line. A good portal for French psychiatry is Psydoc-France (http:// psydoc-fr.broca.inserm.fr).

\section{PATIENT INFORMATION}

The vast American Mental Help Net (http:// mentalhelp.net) is probably one of the largest web sites for patients although the sheer amount of information available here may be overwhelming. A high quality British patient web site is the National electronic Library for Mental Health (www.nelmh.org), part of NHS Direct UK. At present there are only sections on depression, suicide, and schizophrenia but these are detailed and supplemented with video material. This web site will be expanding to include a broad range of mental health topics, as well as a section for professionals, with a stringent editorial policy. The American Psychiatric Association (www. psych.org) and Royal College of Psychiatrists (www.rcpsych.ac.uk) sites have carefully selected links to patient information. There are also disorder specific sites for patients at www. schizophrenia.com and the UK based Depression Alliance (www.depressionalliance.org). For lighter relief, you can listen to "radio shows" on a variety of mental health topics such as lying, borderline personality disorder, and pain at the Infinite Mind (www.lcmedia.com/mindprgm.htm).

Abbreviations: $f M R I$, functional magnetic resonance imaging 
Table 1 Some useful web sites for psychiatry and neuropsychiatry

\begin{tabular}{|c|c|c|}
\hline Site name & URL & Description \\
\hline \multicolumn{3}{|l|}{ General psychiatry sites } \\
\hline fal Health^ & www.mentalhealth.com & $\begin{array}{l}\text { - Good all round site with DSM-IV and ICD } \\
\text { definitions }\end{array}$ \\
\hline National Institute of Mental Health (US)* & www.nimh.nih.gov & $\begin{array}{l}\text { - Large professional and patient resource; } \\
\text { information on trials }\end{array}$ \\
\hline National electronic Library for Mental Health (UK)* $\dagger$ & www.nelmh.org & $\begin{array}{l}\text { - Limited to schizophrenia, depression, and } \\
\text { suicide but a growing reliable resource }\end{array}$ \\
\hline Institute of Psychiatry, London* & www.iop.kcl.ac.uk & $\begin{array}{l}\text { - Institute information and a self help section for } \\
\text { patients }\end{array}$ \\
\hline Centre for Evidence Based Mental Health $\dagger$ & \multirow{2}{*}{$\begin{array}{l}\text { cebmh.warne.ox.ac.uk/cebmh } \\
\text { www.cochrane.org }\end{array}$} & - A starting point for evidence based psychiatry \\
\hline Cochrane Mental Health $\dagger$ & & - Systematic reviews in psychiatry \\
\hline Medscape Psychiatry $\ddagger$ & Psychiatry.medscape.com & - Psychiatry news, conference reports, CME \\
\hline Psydoc-France & \multirow{2}{*}{$\begin{array}{l}\text { psydoc-fr.broca.inserm.fr } \\
\text { www.shef.ac.uk/ psysc/psychotherapy }\end{array}$} & - Good access to French psychiatry \\
\hline Online dictionary of mental health & & $\begin{array}{l}\text { - Not a dictionary but a searchable directory of } \\
\text { mental health sites }\end{array}$ \\
\hline Interactive Testing in Psychiatry & www.med.nyu.edu/Psych/itp.html & - $M C Q$ self testing from New York University \\
\hline \multicolumn{3}{|l|}{ Professional organisations } \\
\hline Royal College of Psychiatrists* $\ddagger$ & www.rcpsych.ac.uk & \\
\hline American Psychiatric Association ${ }^{*} \ddagger$ & www.psych.org & \\
\hline American Neuropsychiatry Association & www. neuropsychiatry.com/ANPA & \\
\hline British Neuropsychiatry Association & www.bnpa.fsnet.co.uk & \\
\hline British Neuropsychological Society & www.hop.man.ac.uk/bns & \\
\hline \multicolumn{3}{|l|}{ Neuropsychiatry } \\
\hline Neuropsychology & www.neuropsychology.co.uk & $\begin{array}{l}\text { - United Kingdom orientated site with journals, } \\
\text { departmental links, and conferences }\end{array}$ \\
\hline Wellcome Department of Imaging Neuroscience & www.fil.ion.ucl.ac.uk & $\begin{array}{l}\text { - Functional imaging centre with downloadable } \\
\text { software }\end{array}$ \\
\hline fMRI Data Center & www.fmridc.org & $\begin{array}{l}\text { - A repository of peer reviewed fMRI studies and } \\
\text { their underlying datasets }\end{array}$ \\
\hline NeuroPsychiatry Reviews & www.neuropsychiatryreviews.com & - Monthly articles, particularly on treatment issues \\
\hline Face Recognition Home Page & www.cs.rug.nl/ peterkr/FACE/face.html & - A starting point for facial science links \\
\hline Visual Science Websites & www.visionscience.com & - A starting point for visual science links \\
\hline \multicolumn{3}{|l|}{ Patient resources } \\
\hline & mentalhelp.net & - Large mental health hub for patients \\
\hline About Mental Health* $\ddagger$ & mentalhealth.miningco.com & - Another American mental health hub site \\
\hline Mind* & www.mind.org.uk & - British mental health charity \\
\hline Depression Alliance* & www. depressionalliance.org & - British patient organisation \\
\hline Schizophrenia.com* & www.schizophrenia.com & - American patient organisation \\
\hline The Infinite Mind* & www.lcmedia.com/mindprgm.htm & $\begin{array}{l}\text { - Library of weekly American internet radio } \\
\text { programmes on mental health topics }\end{array}$ \\
\hline \multicolumn{3}{|l|}{ Directories of psychiatry and psychology journals } \\
\hline Psycline & www.psycline.org & - Journal finder for psychology and social sciences \\
\hline
\end{tabular}

*Recommended for patients; †evidence based; łgood for news. Universal resource locators (URLs) correct on 31 July 2002.

CME, continuing medical education; ICD, International classification of diseases; DSM-IV, Diagnostic and statistical manual of mental disorders, fourth edition; fMRI, functional magnetic resonance imaging; MCQ, multiple choice questions. These URLs are downloadable as a Bookmarks/Favorites file from the JNNP web site (www.jnnp.com).

\section{PROFESSIONAL ORGANISATIONS}

Most of the principal professional organisations in psychiatry, neuropsychiatry, and psychology now have web sites. Table 1 lists the main ones, which usually have links to forthcoming meetings, press releases, etc.

\section{PSYCHIATRY NEWS}

If you want to be kept informed about conferences and recent developments, the American Psychiatric Association web site will take you to their free full text Psychiatric News (http://pn.psychiatryonline.org). Good quality, weekly psychiatric news and conference reports are also available at Medscape Psychiatry \& Mental Health (http://psychiatry. medscape.com) (you need to log in with a password but the service is free).

\section{NEUROPSYCHIATRY}

There are rather fewer resources specifically dedicated to neuropsychiatry and neuropsychology. www.Neuropsychology. co.uk contains conference and departmental information for neuropsychologists in the United Kingdom. NeuroPsychiatry Reviews (www.neuropsychiatryreviews.com) provides three articles a month on neuropsychiatry topics such as poststroke anxiety disorder and psychopathology in cerebellar degeneration. Those involved in neuropsychiatry research may be particularly interested in functional imaging web sites. The Wellcome Department of Imaging Neuroscience (www. fil.ion.ucl.ac.uk) maintains a site that includes, among other things, downloadable statistical parametric mapping software. The fMRI Data Center (www.fmridc.org) is a relatively new web site based in the United States and designed as a 
Table 2 Ten popular psychiatry and neuropsychiatry journal web sites

\begin{tabular}{llll}
\hline Journal name & URL & Free full text availability?* & Email table of contents? \\
\hline Archives of General Psychiatry & archpsyc.ama-assn.org & No & Yes \\
Molecular Psychiatry & www.naturesj.com/mp & No & Yes \\
American Journal of Psychiatry & ajp.psychiatryonline.org & No & Yes \\
British Journal of Psychiatry & bip.rcpsych.org & Articles more than 1 year old & Yes \\
Journal of Clinical Psychiatry & www.psychiatrist.com & No & Yes \\
Biological Psychiatry & www-east.elsevier.com/bps & No & No \\
Schizophrenia Research & www.elsevier.com/locate/schres & No & Yes \\
Psychological Medicine & uk.cambridge.org/journals & No & No \\
Psychosomatic Medicine & www.psychosomatic.org & Articles more than 2 years old Yes & Yes \\
Journal of Neurology, Neurosurgery \& Psychiatry & www.jnnp.com & Articles more than 1 year old & Yes \\
Journal of Neuropsychiatry and Clinical Neurosciences & neuro.psychiatryonline.org & No & Yes \\
Journal of Psychiatry and Neuroscience & www.cma.ca & All articles & No \\
\hline
\end{tabular}

*All of these journals (except Biological Psychiatry) provide full text access by subscription. URLs correct on 31 July 2002 .These URLs are downloadable as a Bookmarks/Favorites file from the JNNP web site (www.jnnp.com).

repository for complete functional magnetic resonance imaging (fMRI) datasets that can be requested to "interpret, analyse, and replicate" studies. The Face Recognition Home Page (www.cs.rug.nl/ peterkr/FACE/face.html) takes you to all things face related such as pages on prosopagnosia and face databases. A good set of links to visual science web sites can be found at www.visionscience.com.

\section{ANTIPSYCHIATRY}

Anyone interested in antipsychiatry material can start at the Citizen Commission on Human Rights (www.cchr.org) where you can read articles entitled Psychiatry betraying and drugging children and Psychiatry destroying religion, creating evil. At Alternative Mental Health Online (www. alternativementalhealth.com/) the treatment of mental illness by solving "nutritional problems, allergies, glandular ailments, heavy metal poisoning, and infections" is discussed.

\section{CYBERCHONDRIA AND ILLNESS TRANSMISSION THROUGH THE INTERNET}

Although not yet in the Oxford English Dictionary, the word "cyberchondria" has been coined to describe the excessive use of internet health sites to fuel health anxiety. ${ }^{3}$ Hypochondriasis is a distressing condition where uncontrollable anxiety about the seriousness of physiological symptoms leads to the persistent seeking of reassurance and medical investigation. Medical information, as well as misinformation, has always been available to those who want it. However, the vast amount of accessible and instant information about symptoms, investigations, and personal stories of illness now on the internet is unprecedented. Additionally, a number of "online diagnosis" sites such as www.medical-library.org or popular CD ROM based tools such as Dr Schueler's Home Medical Advisor provide interactive advice on specific symptoms. These resources have the potential to empower patients to deal with their own minor symptoms but may also generate consultations that may not have otherwise taken place. Studies that have looked at the provision of information for minor symptoms have suggested that consultation rates are not greatly affected. ${ }^{45}$ These studies may have found an increase in health anxiety in some patients counterbalanced by a decrease in consultation by others. ${ }^{6}$

On a more sinister note, Elaine Showalter has proposed in her book Hystories ${ }^{7}$ that the internet offers a new route for the spread of illness-the spread of pathogenic ideas, a means of transmission that she proposes can fuel epidemics of conditions such as the Gulf War syndrome and myalgic encephalomyelitis.

The internet, like any significant technological advance, has been promoted as a mainly positive force in medicine. As time passes, it is likely that its potential to damage human health will also become clearer. The overall balance of good and harm remains to be seen.

\section{ACKNOWLEDGEMENTS}

Thank you to Stephen Lawrie and Andrew McIntosh from the Department of Psychiatry, University of Edinburgh for their web site suggestions.

\section{Authors' affiliations}

J Stone, Department of Clinical Neurosciences, Western General Hospital, Crewe Rd, Edinburgh EH4 2XU, UK

M Sharpe, Department of Psychiatry, Royal Edinburgh Hospital, Morningside Park, Edinburgh EH10 5HF, UK

Competing Interests: None declared

\section{REFERENCES}

1 Al Shahi R, Sadler M, Rees G, et al. The internet. J Neurol Neurosurg Psychiatry 2002;73:619-28.

2 Grohol JM. The insider's guide to mental health resources online: 2002/2003 edition. New York: Guilford Press, 2002.

3 Vallely P. Are you a cyberchondriac? Independent 18 April 2001. http://www.independent.co.uk/story.jsp?story $=67141$

4 Heaney D, Wyke S, Wilson P, et al. Assessment of impact of information booklets on use of healthcare services: randomised controlled trial. BM 2001;322:1218-21.

5 Little P, Somerville J, Williamson I, et al. Randomised controlled trial of self management leaflets and booklets for minor illness provided by post. BM 2001;322:1214-17

6 Usherwood TP. Development and randomized controlled trial of a booklet of advice for parents. Br J Gen Pract 1991;41:58-62.

7 Showalter E. Hystories. London: Picador, 1997. 